\title{
THREE UNPUBLISHED B YZANTINE LEAD SEALS FROM WESTERN ASIA MINOR (WITH AN APPENDIX ON AN AMULET FROM IZMIR)
}

\author{
Ergün Laflı \\ Dokuz Eylül Üniversitesi, Izmir, Turkey \\ Maurizio Buora \\ Societa Friulana di Archeologia odv, Udine, Italy
}

\begin{abstract}
This paper presents three formerly unpublished Byzantine lead seals and an amulet that were examined in the archaeological museum of Izmir (nos. 1, 3 and figs. 5a-b) and Akhisar (no. 2) in western Turkey. They date from the $7^{\text {th }}$ to the $13^{\text {th }}$ century AD. The seal of a Manuel apo hypaton (no. 1) reveals the relations between the court of Constantinople and the city of Smyrna in the $7^{\text {th }}$ century AD. Another one of Ioannes hypatos spatharios (no. 2) comes from Akhisar ( $8^{\text {th }}$ century AD). No. 3 is dated to the $11^{\text {th }}$ and $12^{\text {th }}$ centuries AD. A lead amulet at the appendix part (figs. 5a-b), which perhaps originates from the Early Byzantine period, bears the name of Sabaốth.

Key words: Byzantine lead seals, amulet, apo hypaton, hypatos and imperial spatharios, Sabaốth, sigillography, Byzantine period, Izmir, Akhisar, Western Asia Minor, Turkey.

Citation. Laflı E., Buora M. Three Unpublished Byzantine Lead Seals from Western Asia Minor (With an Appendix on an Amulet from Izmir). Vestnik Volgogradskogo gosudarstvennogo universiteta. Seriya 4. Istoriya. Regionovedenie. Mezhdunarodnye otnosheniya [Science Journal of Volgograd State University. History. Area Studies. International Relations], 2020, vol. 25, no. 6, pp. 160-167. DOI: https://doi.org/10.15688/ jvolsu4.2020.6.12
\end{abstract}

\section{ТРИ НЕОПУБЛИКОВАННЫЕ ВИЗАНТИЙСКИЕ СВИНЦОВЫЕ ПЕЧАТИ ИЗ ЗАПАДНОЙ МАЛОЙ АЗИИ (С ПРИЛОЖЕНИЕМ, ВКЛЮЧАЮЩИМ АМУЛЕТ ИЗ ИЗМИРА)}

\author{
Эргюн Лафлы \\ Университет Докуз Эйлюль, г. Измир, Турция \\ Маурицио Буора \\ Фриульское археологическое общество, г. Удине, Италия
}

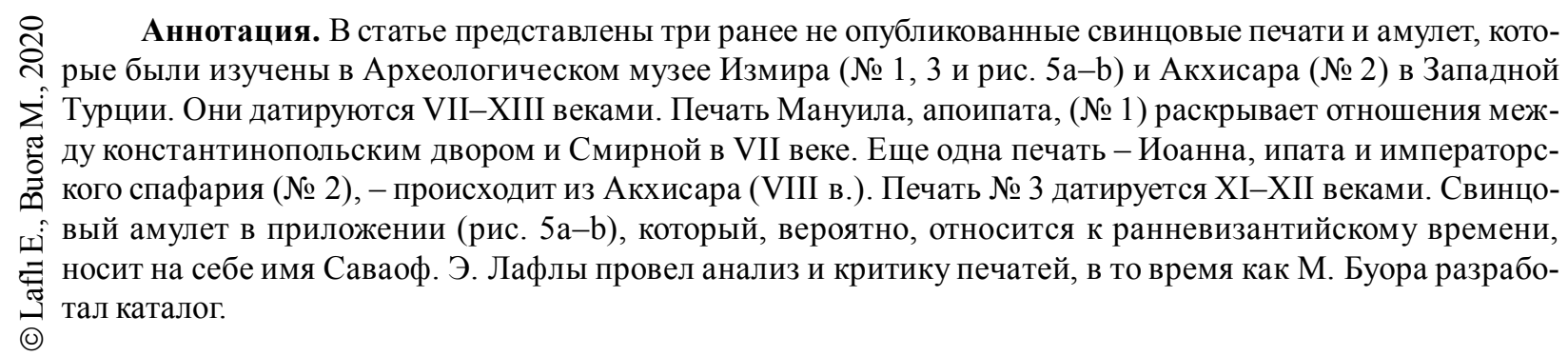


Ключевые слова: византийские свинцовые печати, амулет, апоипат, ипат и императорский спафарий, Саваоф, сфрагистика, византийский период, Измир, Акхисар, Западная Малая Азия, Турция.

Цитирование. Лафлы Э., Буора М. Три неопубликованные византийские свинцовые печати из Западной Малой Азии (с приложением, включающим амулет из Измира) // Вестник Волгоградского государственного университета. Серия 4, История. Регионоведение. Международные отношения. - 2020. - Т. 25, № 6. С. 160-167. - (На англ. яз.). - DOI: https://doi.org/10.15688/jvolsu4.2020.6.12

\section{Introduction}

The number of lead seals in the eastern world is estimated at about 80,000 , most of which remain as unpublished [11, p. 150]. Our contribution is to present three of these unpublished ones in two Turkish museums (fig. 1). Only few seals of the archaeological museum of Izmir have already been published and the ones in the depot of courtial antiquities are not known in scholarly literature. Their dating varies mostly from the seventh to the $13^{\text {th }}$ centuries A.D. Most of these seals do not have good conservation conditions. They include the names of dignitaries of the Byzantine Empire (apo eparkhon, patrikios and strategos etc.) and also of an empress. In the collection of the archaeological museum of Izmir there is a lead amulet of particular interest which was inserted in an appendix part and bears the name of Sabaóth, one among the different names of the Hebrew god.

\section{Catalogue $^{1}$}

No. 1

The lead seal of Manuel apo hypaton (figs. 2a-b).

Depository and provenance: Archaeological museum of Izmir, in the depot of courtial antiquities, accession no. 2016.861.4. It was given to the museum by the Second Civil Court of First Instance in Izmir in 2016 before of which it was belonging to a private collection in the surrounding of Izmir.

State of preservation: Damaged on border. Corrosion.

Measurements: Diameter $20 \mathrm{~mm}$ and field diameter $15 \mathrm{~mm}$.

Transcription - Obverse: Wreath border.

$$
+\mathrm{M}-
$$

2 ANOY $\mathrm{H} \wedge$
Reverse: Wreath border.

$$
\begin{array}{ll} 
& \text { A PO } \\
2 & \text { Y } \\
& W N
\end{array}
$$

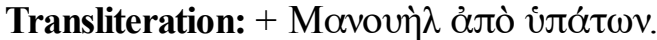

Translation: Of Manouel(ou), one of the hypatoi.

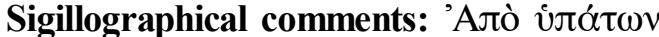
corresponds to the rank class of the former consuls, consularis in Latin, later occasionally also exconsul or similar ${ }^{2}$. It was also a name for certain senatorial provincial governors of provinciae inermes, as in Notitia Dignitatum well attested in the fourth and fifth centuries A.D. But it also became more and more a title, especially in the seventh century A.D., from which our seal originates. In this specific case of the seal from Izmir, it is uncertain whether it is an office or a title.

Comparandum: There are a number of seals of apo hypaton in the Dumbarton Oaks and Fogg Collections, mostly dating to the seventh century A.D. [14, p. 110], but a Manuel with the title $\dot{\alpha} \pi$ ò $\dot{\pi} \alpha \dot{\tau} \omega v$ is so far unknown otherwise. In the Dumbarton Oaks Collection a very similar unpublished lead seal with the accession no. DO 58.106.1622 is housed ${ }^{3}$.

Dating: Seventh century A.D.

\section{No. 2}

The lead seal of Ioannes hypatos and imperial spatharios (fig. 3).

Depository: Museum of Akhisar, Byzantine Thyatira, in a display case in the hall of small finds.

State of preservation: Damaged on border. Corrosion.

Measurements: Diameter $22 \mathrm{~mm}$ and field diameter $16 \mathrm{~mm}$.

Transcription - Obverse: Cruciform invocative monogram with inscription in the quarters; wreath border.

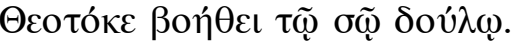


Reverse: Inscription in four lines, with cross above and below.

$$
+10-
$$

$2 \quad \mathrm{ANNH} \vee \mathrm{V}-$

ATU C BAC-

$4 \quad I \wedge I K U C \Pi-$

$A \Theta A P I U$

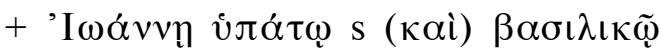
$\sigma \pi \alpha \theta \alpha \rho i ́ \omega$

Translation: Mother of God, help your servant John, hypatos and imperial spatharios.

Sigillographical remarks: 'Y $\mathrm{\pi} \alpha \tau \mathrm{T}$, , consul,

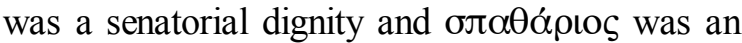
imperial title, as there were also active spatharioi at the imperial court in Constantinople ${ }^{4}$. Throughout the sixth to the ninth centuries A.D. there is an ample sigillographical evidence of functionaries bearing this the title, usually attached to mid-level administrative and fiscal posts, but the title hypatos lost its importance over time. Both in imperial and ecclesiastical administration many dignitaries named with the common name John (properly Ioannes) are known by the Byzantine world.

Comparandum: A very similar lead seal with the accession no. DO 47.2.873 in the Dumbarton Oaks Collection in Washington, DC and a further one in the private collection of Yavuz Tatış in Izmir [5, no. 5.46] are housed (cf. the latter publication also for the reference of a similar seal in the corpus of Zacos - Veglery, i.e. [16]).

Dating: It is noteworthy that in the seventh century A.D. we often find the title of hypatos and spatharios combined $[4, \text { p. } 23]^{5}$. The type of invocation of the obverse and the titling, however, correspond to the examples of the eighth-ninth century A.D.

\section{No. 3}

The lead seal of Romanos IV, Eudokia, Michael VII, Constantios and Andronikos (figs. 4a-b).

Depository and provenance: Archaeological museum of Izmir, in the depot of courtial antiquities, accession no. 2017.33.123.1. It was given to the museum by the 33. Civil Court of First Instance in Izmir in 2018 before of which it was belonging to a private collection in Izmir.

State of preservation: Corrosion. Otherwise well preserved.

Measurements: Diameter $30 \mathrm{~mm}$ and field diameter $28 \mathrm{~mm}$.
Transcription - Obverse: Three full-length figures: in the center, Christ bearded wearing a tunic and himation and standing on a dais. He has a nimbus cruciger. With uplifted arms he places a cross-topped crown on the bearded head of the emperor Romanos on the left and a crown with three triangular projections on the head of Eudokia on the right. Romanos wears a loros and holds his right hand before his chest and a globus cruciger in his left hand. Eudokia wears a loros and holds her left hand before her chest and a globus cruciger in her right hand. At left and right of Christ's head,

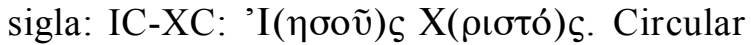
inscription. Border of dots.

PUMAN $\in V \triangle O K I A$

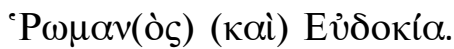

Reverse: Three full-length figures, all of whom stand on daises. In center, Michael VII, taller than his brothers, standing, wearing a crown with a cross and a loros, and holding a labarum in his right hand and an akakia in his left. He is flanked by the shorter, beardless figures of Constantios on the left and Andronikos on the right. Each wears a crown with a cross and a loros. Constantios holds a globus surmounted by a trefoil ornament in his right hand and an akakia in his left. Andronikos holds an akakia in his right hand and a globus surmounted by a trefoil ornament in his left. Circular inscription. Border of dots.

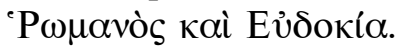

$2 \mathrm{~K} \omega v(\sigma \tau \alpha \dot{\alpha} v \tau \iota \varsigma) . \mathrm{M}(\mathrm{\iota}) \chi(\alpha \hat{\eta} \lambda)$.

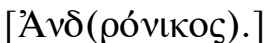

Translations: Romanos and Eudokia.

Constantios. Michael. Andronikos.

Sigillographical remarks: On coins, Michael VII and his brothers appear on the obverse, convex side, while Christ, Romanos, and Eudokia are portrayed on the reverse, concave side. On the seals, lacking any indicator of which side is which, it is conventional to reverse the order, placing the figure of Christ on the obverse. Perhaps forgery (?).

The seals and coins of Romanos's reign are the most cluttered examples from the whole Byzantine period. During Romanos's reign, Constantine's third son, Andronikos, was associated in rule, and on his seals and coins the nominal senior emperor appears vastly outnumbered by the family of Constantine X. Romanos and Eudokia appear either side of Christ, who blesses them. On the reverse the three sons of Constantine $\mathrm{X}$ are shown 
in their imperial regalia. Although interpretation of the seals follows the convention of placing the senior emperor on the obverse, the sides are reversed when considering the coins, the concavity of which allows us to determine which was the top die.

Comparanda: $[9$, no. $82.3 ; 1$, p. $72-75$, nos. 128-136; 16, no. 93a].

Dating: The era of Romanos IV Diogenes, i.e. A.D. $1068-1071$.

\section{Appendix}

A lead amulet for Sabaōth from Izmir (figs. 5a-b).

Depository and provenance: Archaeological museum of Izmir, in the depot of courtial antiquities, accession no. 2016.861.3. It was given to the museum by the Second Civil Court of First Instance in Izmir in 2016 before of which it was belonging to a private collection in the surrounding of Izmir.

State of preservation: Damaged on border. Corrosion.

Measurements: Max. diameter $13 \mathrm{~mm}$.

Description: The lead object was an amulet and there was a loop for hanging on neck or somewhere else. Such amulets were worn by Christians of different beliefs, not necessarily gnostics.

Transcription: On the obverse side CABA $\Omega(\Theta)(\Sigma \alpha \beta \alpha \omega \theta$; Sabaóth / zebaot) in the centre and on the reverse side IA $\Omega$ ('I $\alpha \tilde{\omega})$ in the lower part.

Sigillographical comments: This amulet belongs to the circle 'I $\alpha \tilde{\omega}, \Sigma \alpha \beta \alpha \omega \dot{\theta} \theta$ (in Hebrew צבאות, plural of צבא, which is one of the archontic powers (CG II, I ApocJohn 11.30; 12.20). These names are multitudinously attested and invoked in magical literature, especially on amulets $[8$, p. 105 106]. Sabaóth was an epithet of Jewish god in his role as protector of the Israelite army, usually translated (alongside YHWH or Elohim) as "the lord of hosts" [6, p. 186]. It also means hosts or armies. In the gnosticism it is the name of one of the seven chief archons in the Ophite cosmogony.

Comparanda: This category of small amulets is scarcely studied. Campbell Bonner published a book (1951) and two additional articles (1951 and 1954) on magical amulets, with particular reference to the British Museum collections $[2 ; 3]$. Twenty-five years ago, Jeffrey Spier wrote a paper on the amulets recognizing that a large number of pendant-amulets are attributable to the Early Byzantine period. Sometimes the names 'I $\alpha \tilde{\omega} \Sigma \alpha \beta \alpha \omega \theta \theta$ are associated with the image of the oujooßópos, a symbolic depiction of a serpent or dragon eating its own tail [3, p. 150]. The mention of 'I $\alpha \tilde{\omega}$, $\Sigma \alpha \beta \alpha \omega \dot{\theta} \theta$ appears first time on a face of a bronze pendant-amulet which is now housed in the Bible Lands Museum Jerusalem [12, p. 46, fig. 1]. The invocation of divine and angelic names such as Iao, Sabaóth, Adonai or archangels was already an ancient tradition in paganic magic, ultimately derived from a former Jewish practice [13, p. 49].

Dating: Possibly Early Byzantine period.

\section{Conclusion}

These three seals presented above range from the seventh to the $13^{\text {th }}$ century A.D. and provide even just a bit evidence on the Byzantine dignitaries in Asia Minor. The lead amulet at the appendix part (figs. 5a-b), which originates perhaps from the Early Byzantine period, bears the name of Sabaóth that remains as a unique evidence for western Asia Minor.

\section{ENDNOTES}

${ }^{1}$ Nos. 1, 3 and figs. 5a-b from the Archaeological Museum of Izmir were studied with an authorization granted by the Turkish Ministry of Culture and Tourism, Directorate of the Monuments and Museums on April 13, 2010 and enumerated as B.16.0.KVM.0.13.04.00-155.01.(TA10.B81)-77614. The necessary documentation was assembled between June 2010 and May 2017. We would like to thank to Mrs Zuhal Küçükgüney and Ms Necla Okan (both from the Archaeological Museum of Izmir) for their assistance during the study of these objects.

No. 2 from the Museum of Akhisar was studied with an authorization granted by the Turkish Ministry of Culture and Tourism, Directorate of the Monuments and Museums on June 4, 2007 and enumerated as B.16.0.KVM.200.11.02.02.14.01.222.11.(TA07.40/A)116546. The necessary documentation was assembled between August 2007 and May 2016.

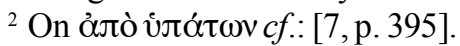

${ }^{3}$ We would like to thank to Professor Werner Seibt (Vienna) who kindly provided this information.

${ }^{4}$ Cf. for these titles: [10, p. 297-298].

${ }^{5}$ Furthermore, in the auction made by Mьnz Zentrum, sale no. 96 (10-12 September 1998) a lead seal of an Ioannes hypatos and protospatharios was sold, $c f .[15$, p. 184, no. 1340]. 


\section{ВИЗАНТИЙСКАЯ СФРАГИСТИКА}

\section{ПРИЛОЖЕНИЕ}

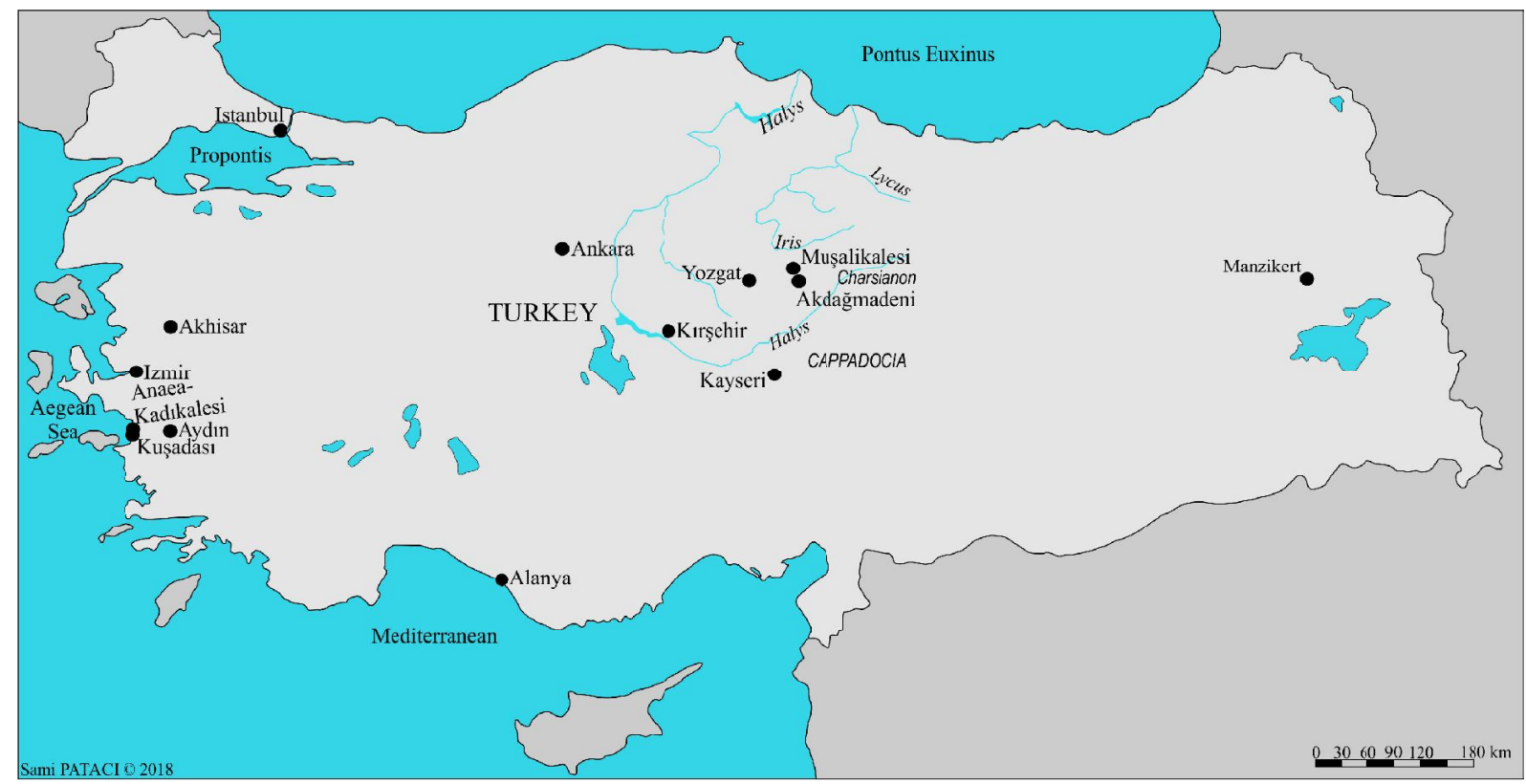

Fig. 1. Places in Asia Minor and elsewhere referred to in the text (by S. Patac1, 2018)
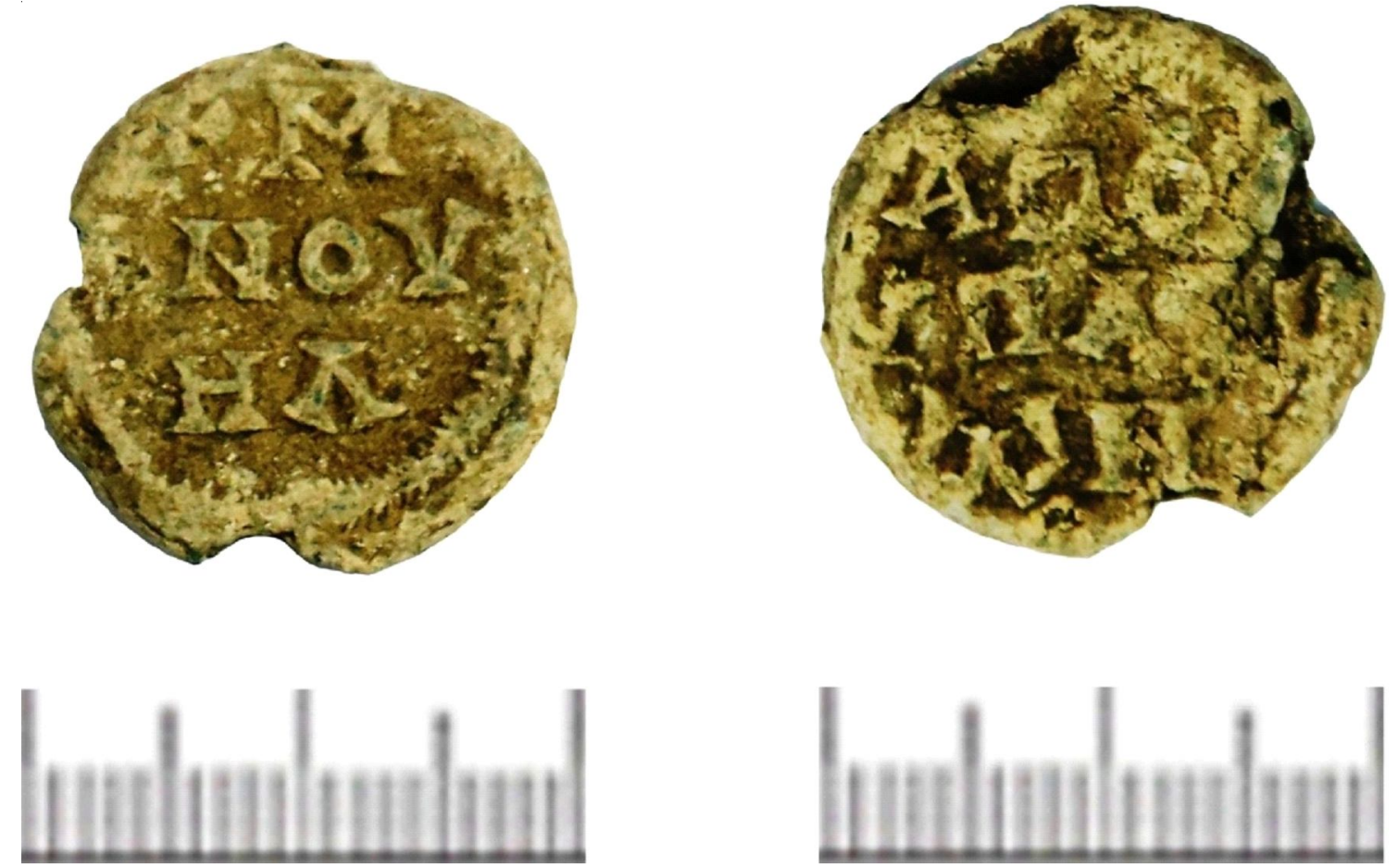

Figs. 2a-b. The lead seal of Manuel apo hypaton. Archaeological museum of Izmir, accession no. 2016.861.4 

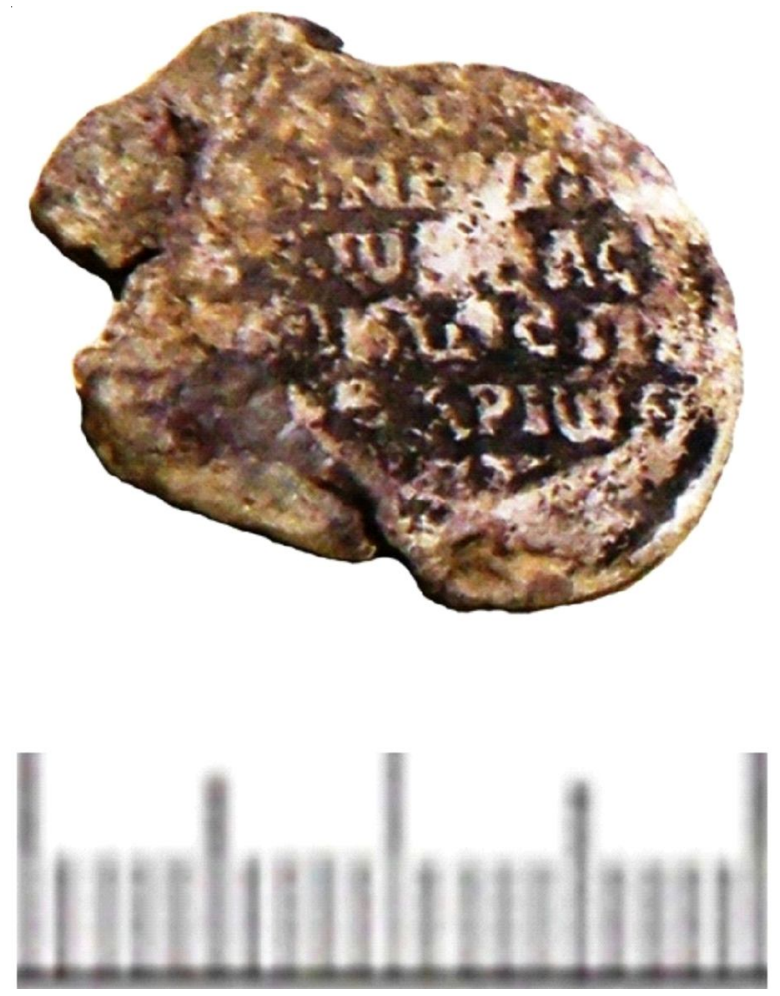

Fig. 3. The lead seal of Ioannes hypatos and imperial spatharios. Museum of Akhisar
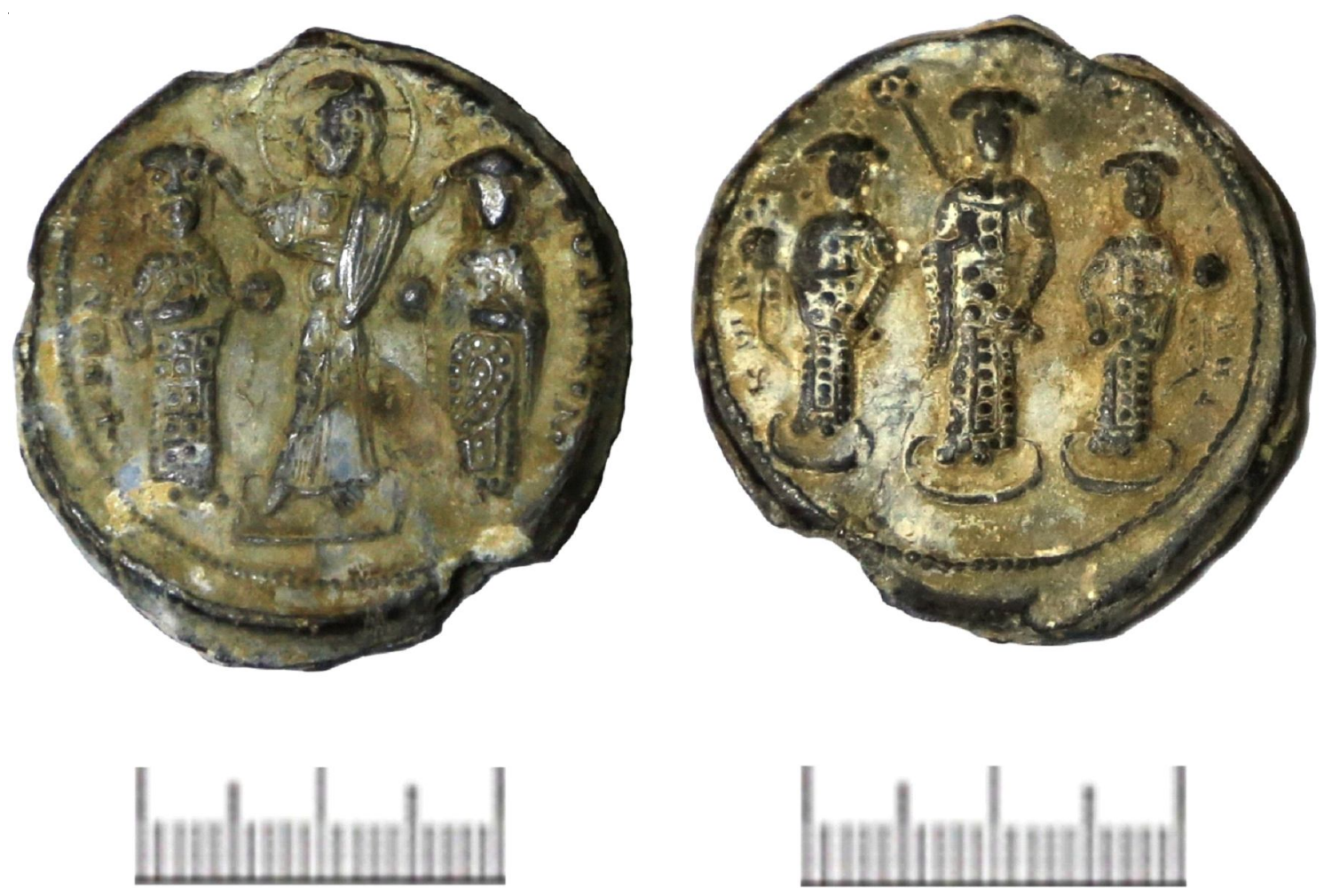

Figs. 4a-b. The lead seal of Romanos IV, Eudokia, Michael VII, Constantios, and Andronikos. Archaeological museum of Izmir, accession no. 2017.33.123.1 


\section{ВИЗАНТИЙСКАЯ СФРАГИСТИКА}
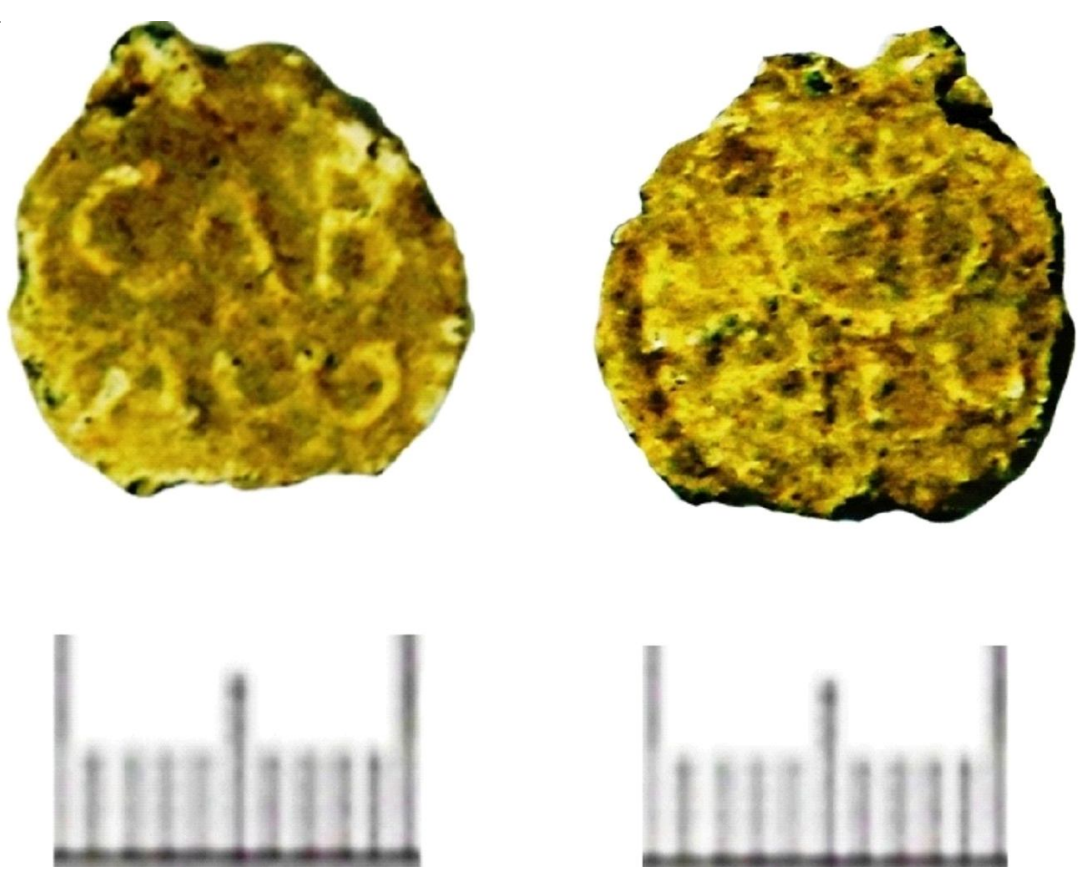

Figs. 5a-b. A lead amulet for Sabaốth. Archaeological museum of Izmir, accession no. 2016.861.3 


\section{REFERENCES}

1. Sokolova I.V. Gosudarstvennyy Ermitazh. Pechati vizantiyskikh imperatorov. Katalog kollektsii [The State Hermitage Museum. Byzantine Imperial Seals. The Catalogue of the Collection]. Saint Petersburg, Izd-vo Gosudarstvennogo Ermitazha Publ., 2007. 120 p.

2. Bonner C. Amulets Chiefly in the British Museum. Hesperia. The Journal of the American School of Classical Studies at Athens, 1951, vol. 20, no. 4, pp. 301-345. URL: http://www.jstor.org/stable/ 146801 (accessed 1 November 2020).

3. Bonner C. A Miscellany of Engraved Stones. Hesperia. The Journal of the American School of Classical Studies at Athens, 1954, vol. 23, no. 2, pp. 138-157. URL: http://www.jstor.org/stable/146693 (accessed 1 November 2020).

4. Bury J.B. The Imperial Administrative System in the Ninth Century: with a Revised Text of the Kletorologion of Philotheos. Cambridge, Cambridge University Press, 2015. 186 p.

5. Cheynet J.-C. Les sceaux byzantins de la collection Yavuz Tatıss. Izmir, Private edition, 2019. 464 p.

6. Erharter H. Sabaoth. Buchberger M., ed. Das Lexikon für Theologie und Kirche (LThK). Vol. 9: Pearson bis Samuel. Freiburg im Breisgau, Verlag Herder, 1999. P. 186.

7. Haldon J.F. Byzantium in the Seventh Century. The Transformation of a Culture. Cambridge; New York, NY, Cambridge University Press, 1990. xxviii, 486 p.

8. Mastrocinque A. Perseus and Sabaoth in magic arts and oriental beliefs. Suárez de la Torre E., Pérez Jiménez A., eds. Mito y Magia en Grecia y Roma. Barcelona, Universitat Pompeu Fabra, Libros Pórtico, 2013, pp. 103-116. (Supplementa MHNH, Estudios de astrología, magia y religión antiguas; vol. 1).
9. Nesbitt J., Morrison C. Catalogue of Byzantine Seals at Dumbarton Oaks and in the Fogg Museum of Art. Vol. 6: Emperors, Patriarchs of Constantinople, Addenda. Washington, DC, Dumbarton Oaks Research Library and Collection, 2009. xii, 234 p. (Dumbarton Oaks Collection Series).

10. Oikonomidès N. Les listes de préséance byzantines des $I X^{e}$ et $X^{e}$ siècles. Introduction, texte et commentaire. Paris, Centre national de la recherche scientifique, 1972. 403 p. (Le monde byzantin).

11. Seibt W. The Civil Administration of Byzantine Iberia According to the Seals.

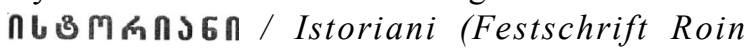

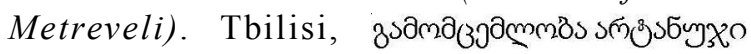
(Gamomcemloba Artanuji), 2009, pp. 150-157.

12. Spier J. Medieval Byzantine magical amulets and their tradition. Journal of the Warburg and Courtauld Institutes, 1993, vol. 56, pp. 25-62. URL: http:// www.jstor.org/stable/751363 (accessed 1 November 2020).

13. Spier J. An antique magical book used for making sixth-century amulets? Dasen V., Spieser J.M., eds. Les savoirs magiques et leur transmission de l'Antiquité à la Renaissance. Florence, Sismel Edizioni del Galluzzo, 2014, pp. 43-66. (Micrologus' Library; vol. 60).

14. Stephenson P. The Serpent Column Fountain. Shilling B., Stephenson P., eds. Fountains and Water Culture in Byzantium. Cambridge, New York, Cambridge University Press, 2016, pp. 103-129.

15. Wassiliou-Seibt A.-K. Catalogue of Auctions (2002-2006). Studies in Byzantine Sigillography, 2010, vol. 10, pp. 155-196.

16. Zacos G., Veglery A. Byzantine Lead Seals. Vol. 1, pt. 1, nos. 1-1095. Imperial Seals, $V^{\text {th }}$ to $X V^{\text {th }}$ Centuries; Non-imperial Seals, VIth to $I^{\text {th }}$ centuries. Basel, J.J. Augustin, 1972. xxxiv, 704 p.

\section{Information About the Authors}

Ergün Laflı, Doctor, Professor, Edebiyat Fakültesi, Arkeoloji Bölümü, Dokuz Eylül Üniversitesi, Oda No A-418, Tınaztepe/Kaynaklar Yerleşkesi, Buca, TR-35160 Izmir, Turkey, elafli@yahoo.ca, http://deu.academia.edu/ErgunLAFLI, https://orcid.org/0000-0002-4722-5018

Maurizio Buora, Doctor, Societa Friulana di Archeologia odv, Via Micesio 2, Torre di Porta Villalta, I-33100 Udine, Italy, mbuora@libero.it, https://independent.academia.edu/MBuora, https://orcid.org/0000-0002-5746-8312

\section{Информация об авторах}

Dr Эргюн Лафлы, профессор классической археологии, факультет литературы, кафедра археологии, Университет Докуз Эйлюль, Oda No A-418, Tinaztepe/Kaynaklar Yerleşkesi, Buca, TR-35160 г. Измир, Турция, elafli@yahoo.ca, http://deu.academia.edu/ErgunLAFLI, https://orcid.org/0000-0002-4722-5018

Dr Маурицио Буора, Фриульское археологическое общество, Via Micesio 2, Torre di Porta Villalta, I-33100 г. Удине, Италия, mbuora@libero.it, https://independent.academia.edu/MBuora, https://orcid.org/0000-0002-5746-8312 